\title{
Ion transport in cultured pig tracheal submucosal gland acinar cells studied by X-ray microanalysis
}

\author{
A-L. Zhang, G.M. Roomans
}

Ion transport in cultured pig tracheal submucosal gland acinar cells studied by X-ray microanalysis. A-L. Zhang, G.M. Roomans. CERS Journals Ltd 1997.

ABSTRACT: The submucosal glands of the airway may contribute more to the airway fluid than the surface epithelium. The cellular mechanisms underlying the regulation of electrolyte and water transport in airway submucosal glands are, however, still poorly understood. Therefore, we attempted to establish a cell culture system to facilitate study of this regulation.

Acinar cells were isolated by enzymatic disaggregation from pig tracheal submucosal tissue and cultured on a plastic substrate coated with human placental collagen. The fine structure of the cells in confluent culture was studied by conventional transmission electron microscopy. The elemental content in resting cells and stimulated cells grown on a permeable substrate was studied by X-ray microanalysis.

The cultured cells retained structural characteristics (microvilli, secretory granules and desmosomes) of in situ epithelia. The total intracellular $\mathrm{Cl}$ and $\mathrm{K}$ concentrations significantly decreased after stimulation with the cholinergic agonist acetylcholine, the predominantly alpha-adrenergic agonist norepinephrine, or the beta-adrenergic agonist isoproterenol. Both ionomycin and 8-bromoadenosine $3 ': 5^{\prime}$-cyclic monophosphate (8-bromo-cAMP) caused a marked decrease of the intracellular $\mathrm{Cl}, \mathrm{K}$ and $\mathrm{Na}$ concentrations. $\mathrm{Cl}^{-}$secretion induced by acetylcholine was inhibited by $\mathrm{Cl}^{-}$channel blockers anthracene-9-carboxylic acid and 5-nitro-2(3-phenylpropyl-amino)-benzoic acid (NPPB), but $\mathrm{Cl}^{-}$efflux induced by 8-bromocAMP was blocked only by NPPB. The intracellular $\mathrm{Cl}$ and $\mathrm{Na}$ content significantly increased and the cellular $K$ content markedly decreased after treatment with ouabain.

These results indicate that the cultured acinar cells maintained the structural and functional characteristics of in situ tissue and that this system is suitable for studying aspects of ion and water transport by the airway submucosal gland cells. Eur Respir J 1997; 10: 2204-2209.
Dept of Human Anatomy, University of Uppsala, Uppsala, Sweden.

\author{
Correspondence: G.M. Roomans \\ Dept of Human Anatomy \\ University of Uppsala \\ Box 571 \\ S-751 23 Uppsala \\ Sweden
}

Keywords: Adrenergic agonist

airway submucosal gland

cholinergic

elemental content

primary cell culture

$\mathrm{X}$-ray microanalysis

Received: July 161996

Accepted after revision May 101997

This study was financially supported by grants from the Swedish Heart-Lung Foundation, and the Swedish Medical Research Council (project 07125).
The human airway is covered by a thin layer of secretion, which is critical for the normal function of the respiratory system. This airway secretion consists mainly of glycoproteins, electrolytes and water, and is produced by the surface epithelium and the tracheobronchial submucosal glands. There is evidence to indicate that the tracheobronchial submucosal glands contribute more to the airway secretion than the surface epithelium. Therefore, the role of the tracheobronchial glands in diseases such as cystic fibrosis (CF) may be more important than that of the surface epithelium. The evidence mentioned is the following: 1) in the respiratory system of healthy adult humans, the volume of the submucosal gland cells exceeds that of the surface mucous epithelial cells (goblet cells) by a ratio of about 40:1 [1]; 2 ) the only pathological change observed in postmortem examinations of newborns with $\mathrm{CF}$ is that the gland ducts are obstructed by viscous mucus; 3 ) in the normal human bronchus, the cystic fibrosis transmembrane regulator (CFTR), a $\mathrm{Cl}^{-}$channel, which is defective in patients with $\mathrm{CF}$, is expressed at very low levels in the surface epithelium, but at considerably higher levels in the submucosal glands [2]; and 4) rats have relatively few submucosal glands in the airway wall, and did not develop severe lung complications when a genetic animal model for CF was developed [3].

Although $95 \%$ of the airway secretion consists of water and electrolytes [4], little is known about the cellular mechanisms underlying fluid transport and their regulation in airway epithelium, and in particular, in the submucosal glands. The complex structure of the airway wall makes it difficult to interpret experiments carried out in vivo. Furthermore, the in vivo preparations do not allow investigators to study the cellular mechanisms of secretion by submucosal glands separately. Primary cultures of tracheobronchial submucosal glands have therefore been developed $[5,6]$. Because the structure of pig respiratory tract closely resembles that of humans [7] and is easily accessible, in the present study we used isolated acinar cells from pig tracheal submucosal glands to initiate a cell culture.

It is widely accepted that the directional ion fluxes constitute the driving force for water transport in exocrine glands [8]. X-ray microanalysis was employed in 
the present study to detect changes in elemental content in resting and activated cells. X-ray microanalysis has the advantage that the content of several different elements and changes therein can be studied simultaneously. This technique has been applied to cultured tumour cells, transformed cell lines, and primary cell cultures $[9,10]$.

The aim of this study was to investigate the possibility of setting up a culture of pig tracheal submucosal gland acinar cells to study ion transport at the cellular level by X-ray microanalysis.

\section{Materials and methods}

\section{Materials and solutions}

5-nitro-2-(3-phenylpropyl-amino)-benzoic acid (NPPB) and diphenylamine-2-carboxylate (DPC) were kind gifts from H.C. Englert, Hoechst AG. Unless otherwise stated, all drugs and reagents were purchased from Sigma Chemical Co. (St. Louis, MO, USA) or from Gibco BRL/ Life Technologies (Paisley, UK). Krebs-N-2-hydroxyethylpiperazine-N'-2-ethanesulphonic acid (HEPES) solution (KHS, pH 7.4) consisted of $120 \mathrm{mM} \mathrm{NaCl}, 4 \mathrm{mM}$ $\mathrm{KCl}, 1.2 \mathrm{mM} \mathrm{MgSO} 4,1.2 \mathrm{mM} \mathrm{KH}_{2} \mathrm{PO}_{4}$, and $15 \mathrm{mM}$ HEPES. Standard Ringer's solution (SRS, pH 7.4) contained $140 \mathrm{mM} \mathrm{NaCl}, 5 \mathrm{mM} \mathrm{KCl}, 5 \mathrm{mM}$ HEPES, $1 \mathrm{mM}$ $\mathrm{MgCl}_{2}, 1.5 \mathrm{mM} \mathrm{CaCl} 2$, and $5 \mathrm{mM}$ glucose.

\section{Isolation of acinar cells}

Pig tracheas were obtained from the local slaughterhouse and transported in ice-cold sterile KHS containing antibiotics $\left(100 \mathrm{U} \cdot \mathrm{mL}^{-1}\right.$ penicillin, $100 \mu \mathrm{g} \cdot \mathrm{mL}^{-1}$ streptomycin) to the laboratory. After two rinses in fresh sterile KHS containing antibiotics, the tracheas were cut longitudinally into three pieces. A piece of airway wall was mounted in a stretched position on a dissection tray, and bathed in Hank's balanced salt solution (HBSS, pH 7.4) containing $20 \mathrm{mM}$ HEPES and antibiotics. After the surface epithelium was removed by sharp dissection, the submucosal tissue was dissected from cartilage and adventitia, collected in fresh HBSS, and minced with scissors. Tissue fragments were recovered by centrifugation $(200 \mathrm{~g}, 10 \mathrm{~min})$ and then incubated at $37^{\circ} \mathrm{C}$ in HBSS containing $20 \mathrm{mM}$ HEPES, collagenase type IV (500 U.mL $\left.\mathrm{m}^{-1}\right)$, pancreatic porcine elastase (6 $\left.\mathrm{U} \cdot \mathrm{mL}^{-1}\right)$, hyaluronidase $\left(200 \mathrm{U} \cdot \mathrm{mL}^{-1}\right)$, deoxyribonuclease $\left(10 \mathrm{U} \cdot \mathrm{mL}^{-1}\right)$, penicillin $\left(100 \mathrm{U} \cdot \mathrm{mL}^{-1}\right)$, streptomycin $\left(100 \mathrm{U} \cdot \mathrm{mL}^{-1}\right)$, gentamicin $\left(100 \mu \mathrm{g} \cdot \mathrm{mL}^{-1}\right)$ and amphotericin $\mathrm{B}\left(2.5 \mu \mathrm{g} \cdot \mathrm{mL}^{-1}\right)$ [5-6]. After $2 \mathrm{~h}$ of disaggregation, the disaggregated tissue was recovered by centrifugation (200 g, $10 \mathrm{~min}$ ), washed twice in cell culture medium containing 40\% Ham's F12 medium, 40\% Dulbecco's Modified Eagle Medium (DMEM), 20\% foetal calf serum (FCS) and antibiotics in the concentrations described above.

\section{Initiation of cell culture}

The disaggregated tissue was resuspended in the same culture medium, acinar cell clumps were picked up under a dissecting phase contrast microscope, and 5-10 clumps were cultured in a human placental collagen-coated Petri dish at $37^{\circ} \mathrm{C}$ in $5 \% \mathrm{CO}_{2} / 95 \%$ air. After $24 \mathrm{~h}$, the medium was replaced with serum-free medium composed of 49\% Ham's F12 medium, 49\% DMEM, 2\% Ultraser $\mathrm{G}$ and antibiotics as described above. The medium was changed every 3 days. After 1 week, penicillin, streptomycin, and amphotericin B were omitted, and the concentration of gentamicin was reduced to $50 \mu \mathrm{g}$. $\mathrm{mL}^{-1}$.

\section{Transmission electron microscopy (TEM)}

Cells reaching confluence on plastic substrate and fragments $\left(1 \mathrm{~mm}^{3}\right)$ of tracheal submucosal tissue were fixed with glutaraldehyde $(2.5 \%)$ in $0.1 \mathrm{M}$ cacodylate buffer for $30 \mathrm{~min}$, and washed in $0.1 \mathrm{M}$ cacodylate buffer before postfixation in osmium tetroxide $(1 \%)$ for $30 \mathrm{~min}$. The cells were dehydrated in an ethanol series, and infiltrated in absolute ethanol containing increasing concentrations of Agar 100 Resin (Agar Scientific, Stansted, UK). The resin was polymerized overnight at $60^{\circ} \mathrm{C}$. Sections were cut, contrasted with uranyl acetate and lead citrate, and examined in a Hitachi H-7100 transmission electron microscope (Tokyo, Japan).

\section{Preparation of cultured cells for X-ray microanalysis}

For X-ray microanalysis, after the culture reached confluence, cells were released from the substrate by $0.5 \%$ trypsin and then seeded onto 75 mesh titanium grids (Agar Scientific, Stansted, UK). The grids had been covered with a Formvar (Merck, Darmstadt, Germany) film coated with a thin carbon layer. The grids were sterilized under ultraviolet light before use. The cells were cultured on the grids for 4 or 5 days. In some experiments, after a quick rinse with SRS, the cells were incubated with SRS containing acetylcholine, norepinephrine, isoproterenol, ouabain, ionomycin or 8-bromoadenosine 3 ':5'-cyclic monophosphate (8-bromo-cAMP) (table 1). In other experiments, the effect of different $\mathrm{Cl}^{-}$channel blockers: anthracene-9-carboxylic acid (9AC) [11], NPPB [12], DPC [13] was tested. The cellcovered grids were preincubated with one of the $\mathrm{Cl}^{-}$ channel blockers followed by incubation with acetylcholine or cAMP in the presence of this $\mathrm{Cl}^{-}$channel blocker (table 1). The dose of the agents used in this study is close to the known maximum dose for this or similar cell types [14]. As controls, we used cells incubated with only SRS (for 3 or $5 \mathrm{~min}$ ), 1\% dimethylsulphoxide (DMSO) in SRS, 1\% ethanol in SRS, 0.5 $\mathrm{mM}$ 9-AC, $50 \mu \mathrm{M}$ NPPB or $0.2 \mathrm{mM}$ DPC (for 5 or 7 min). The incubation was terminated by a quick rinse with SRS and the cells were then washed with cold distilled water for 2-3 seconds to remove the salt-rich SRS. After the rinsing, the grids were quickly frozen in liquid propane cooled by liquid nitrogen $\left(-180^{\circ} \mathrm{C}\right)$ and freeze-dried overnight in vacuum at $-80^{\circ} \mathrm{C}$. The freezedried specimens were covered with a conductive carbon layer before analysis. 
Table 1. - Preincubation and incubation protocols of cultured pig tracheal submucosal gland cells

\begin{tabular}{|c|c|c|c|c|c|}
\hline \multicolumn{3}{|c|}{ Preincubation } & \multicolumn{3}{|c|}{ Incubation } \\
\hline Added & $\begin{array}{c}\text { Concentration } \\
\mu \mathrm{M}\end{array}$ & $\begin{array}{l}\text { Time } \\
\text { min }\end{array}$ & Added & $\begin{array}{c}\text { Concentration } \\
\mu \mathrm{M}\end{array}$ & $\begin{array}{l}\text { Time } \\
\text { min }\end{array}$ \\
\hline - & - & - & Acetylcholine & 10 & 5 \\
\hline- & - & - & Norepinephrine & 10 & 5 \\
\hline - & - & - & Isoproterenol & 10 & 5 \\
\hline - & - & - & Ionomycin & 3 & 3 \\
\hline - & - & - & 8-bromo-cAMP & 5 & 3 \\
\hline - & - & - & Ouabain & 1 & 5 \\
\hline \multirow[t]{2}{*}{$9-\mathrm{AC}$} & 500 & 2 & Acetylcholine & 10 & 5 \\
\hline & & & $+9-\mathrm{AC}$ & 500 & \\
\hline \multirow[t]{2}{*}{ NPPB } & 50 & 2 & Acetylcholine & 10 & 5 \\
\hline & & & +NPPB & 50 & \\
\hline \multirow[t]{2}{*}{$\mathrm{DPC}$} & 200 & 2 & Acetylcholine & 10 & 5 \\
\hline & & & $+\mathrm{DPC}$ & 200 & \\
\hline \multirow[t]{2}{*}{$9-\mathrm{AC}$} & 500 & 2 & 8-bromo-cAMP & 200 & 3 \\
\hline & & & $+9-\mathrm{AC}$ & 500 & \\
\hline \multirow[t]{2}{*}{ NPPB } & 50 & 2 & 8-bromo-cAMP & 200 & 3 \\
\hline & & & +NPPB & 50 & \\
\hline \multirow{2}{*}{ DPC } & 200 & 2 & 8-bromo cAMP & 200 & 3 \\
\hline & & & $+\mathrm{DPC}$ & 200 & \\
\hline
\end{tabular}

9-AC: anthracene-9-carboxylic acid; NPPB: 5-nitro-2-(3-phenylpropyl-amino)-benzoic acid; DPC: diphenylamine2-carboxylate; 8-bromo-cAMP: 8-bromoadenosine 3':5'-cyclic monophosphate.

\section{$X$-ray microanalysis}

The specimens were analysed in a Hitachi H7100 electron microscope in the scanning-transmission electron microscopy (STEM) mode at $100 \mathrm{kV}$ with an Oxford Instruments ISIS energy-dispersive spectrometer system (Oxford, UK). Quantitative analysis was carried out by determining the ratio of characteristic counts to the background under the peak $(\mathrm{P} / \mathrm{B})$, and by comparing $\mathrm{P} / \mathrm{B}$ ratios from the cells with those from standards consist- ing of a gelatin/glycerol matrix containing mineral salts in known concentrations [15]. Spectra were acquired for $100 \mathrm{~s}$. Only one spectrum was acquired from each cell.

\section{Statistical analysis}

All values are expressed as mean \pm SEM. Student's ttest was used to evaluate statistical significance. Significance was attributed to probability values of less than 0.05 .

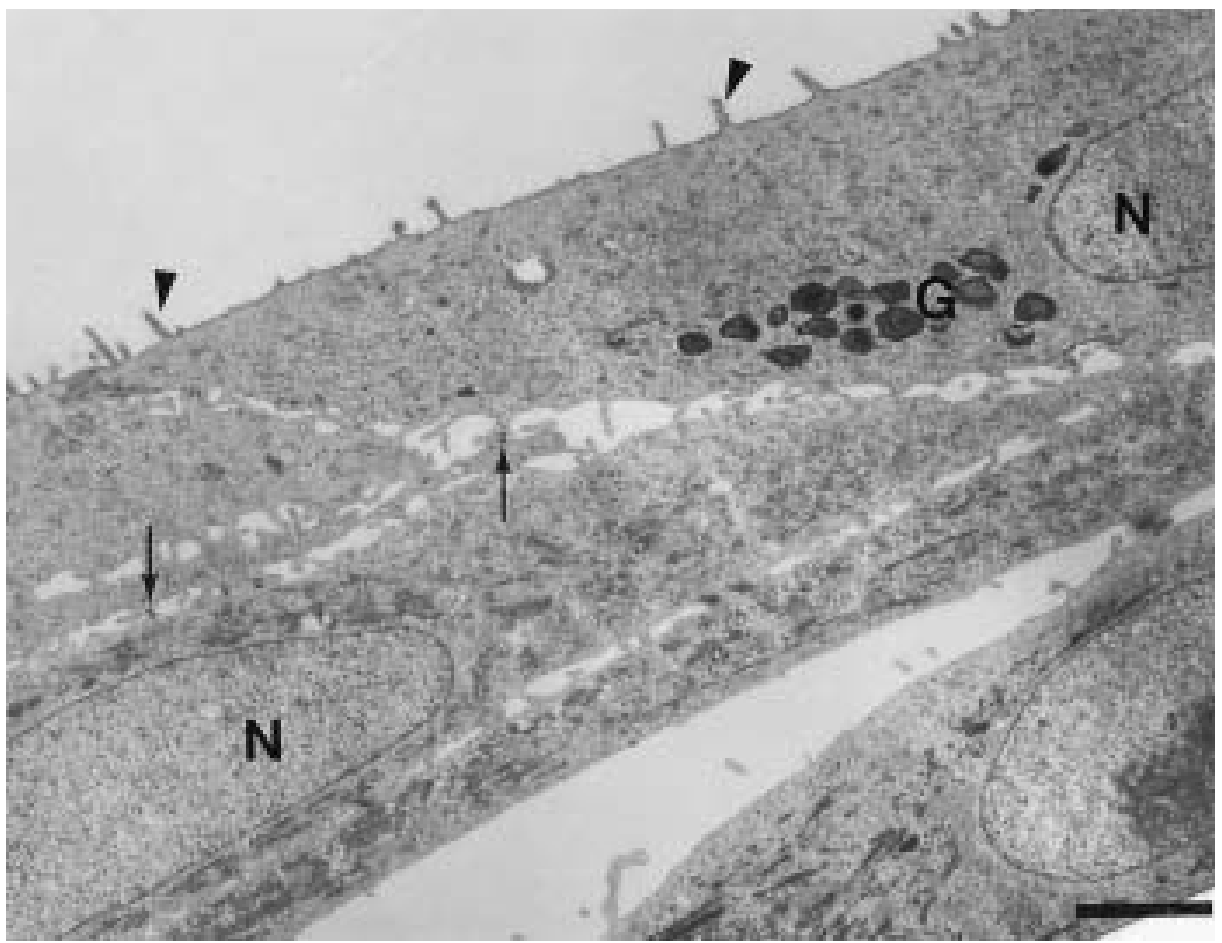

Fig. 1. - Transmission electron micrograph of cultured tracheal submucosal gland acinar cells Desmosomes are indicated by arrows, microvilli by arrowheads. N: nucleus; G: secretory granules. (Internal scale bar $=1.6 \mu \mathrm{m}$ ).

\section{Results}

Transmission electron microscopy of the cultured tracheal gland cells showed that the cells grew 1-3 cell layers thick. A representative image of the cultured cells is shown in figure 1 . The epithelial characteristics of the cells were clearly demonstrated by the presence of microvilli and desmosomes. However, the cultured cells did not contain many secretory granules, in contrast to the acinar cells of the glands in situ (fig. 2). In the cells containing many mitochondria and an extensive Golgi complex, rough endoplasmic reticulum and free ribosomes were also present.

The average concentration of elements measurable by Xray microanalysis in the cultured tracheal gland cells is given in table 2 . The Ca content of the cultured cells was 


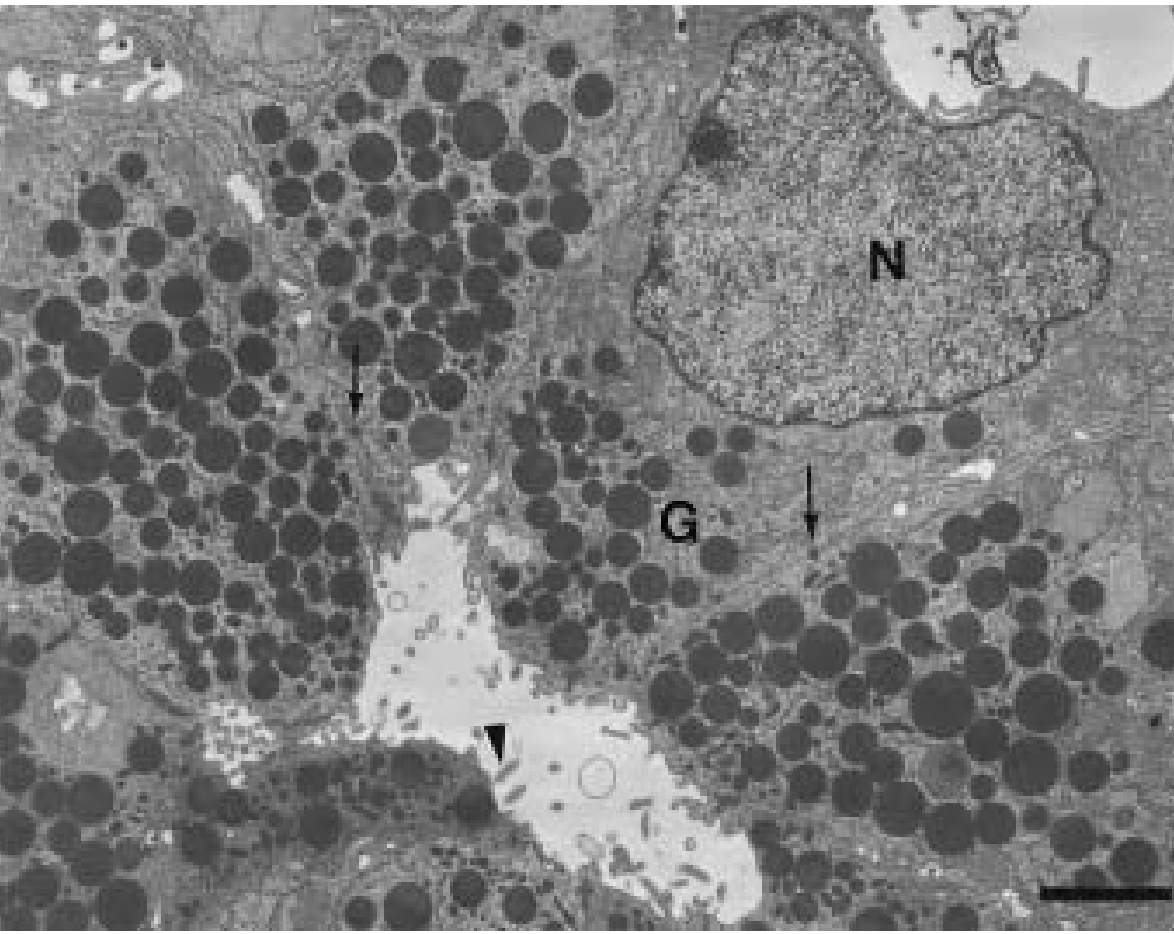

Fig. 2. - Transmission electron micrograph of in situ tracheal submucosal gland acinar cells. Desmosomes are indicated by arrows, microvilli by arrowheads. N: nucleus; g: secretory granules. (Internal scale bar=1.4 $\mu \mathrm{m}$ ).

Table 2. - The elemental content of the cultured tracheal gland cells (control)

\begin{tabular}{cc}
\hline Element & $\begin{array}{c}\text { Concentration } \\
\text { mmol·kg dry weight }\end{array}$ \\
\hline $\mathrm{Na}$ & $90 \pm 11$ \\
$\mathrm{Mg}$ & $32 \pm 3$ \\
$\mathrm{P}$ & $700 \pm 28$ \\
$\mathrm{~S}$ & $161 \pm 11$ \\
$\mathrm{Cl}$ & $272 \pm 13$ \\
$\mathrm{~K}$ & $921 \pm 34$ \\
\hline
\end{tabular}

Results are given as mean \pm standard error. The data are based on four independent experiments using cell cultures set up from three pigs, in which 95 cells were analysed.

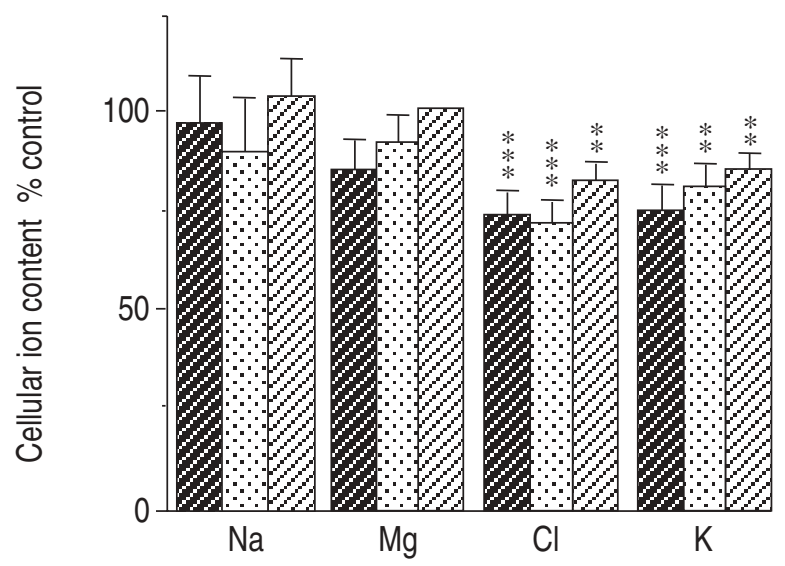

Fig. 3. - Effect of acetylcholine ( $\boldsymbol{Q}$ ), norepinephrine ( $\because$ ) and isoproterenol $(\square)$ on the cellular content of $\mathrm{Na}, \mathrm{Mg}, \mathrm{Cl}$ and $\mathrm{K}$ in cultured pig tracheal submucosal gland acinar cells. The data are expressed as percentage of the control value. Thin bars indicate standard errors. The data are based on four experiments using cell cultures set up from 3 pigs. In each experiment, about 15 cells were analysed. $* *: \mathrm{p}<0.01 ; * * *: \mathrm{p}<0.001$, compared to control. generally below the detection limit of the instrument.

The intracellular $\mathrm{K}$ and $\mathrm{Cl}$ concentrations significantly decreased after stimulation with acetylcholine, norepinephrine or isoproterenol, but no significant changes in the cellular content of $\mathrm{Na}$ and $\mathrm{Mg}$ were observed (fig. 3). Treatment with ionomycin or 8-bromo-cAMP caused a marked decrease of the cellular content of $\mathrm{Na}, \mathrm{Cl}$ and $\mathrm{K}$ (fig. 4).

The intracellular $\mathrm{Na}$ and $\mathrm{Cl}$ content markedly increased while the cellular K content significantly decreased after 5 min of treatment with $1 \mathrm{mM}$ ouabain (fig. 5).

A $30 \%$ decrease in the cellular content of $\mathrm{Cl}$ induced by acetylcholine was reduced to a $10 \%$ decrease by $9-\mathrm{AC}$, while the decrease in the intracellular $\mathrm{K}$ content was not affected. However, 9-AC did not block the $\mathrm{Cl}^{-}$ and $\mathrm{K}^{+}$secretion induced by 8-bromo-cAMP (fig. 6). NPPB significantly inhibited the $\mathrm{Cl}^{-}$and $\mathrm{K}^{+}$secretion induced by acetylcholine or cAMP (fig. 6). DPC did not affect the changes in the cellular content of $\mathrm{Cl}$ and $\mathrm{K}$ elicited by either acetylcholine or 8-bromo-cAMP (not shown). The $\mathrm{Cl}^{-}$channel blockers 9-AC, NPPB or DPC alone did not affect the elemental content of the cells (not shown). Also, DMSO or ethanol in the concentration needed to dissolve the $\mathrm{Cl}^{-}$channel blockers and ionomycin did not cause significant changes in elemental content of the cells (not shown).

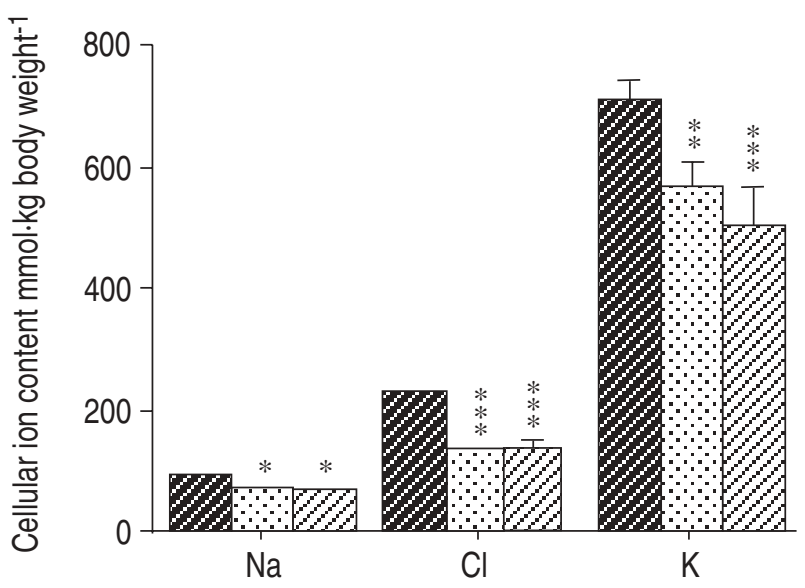

Fig. 4. - Effect of ionomycin and 8-bromo-cAMP on the cellular content of $\mathrm{Na}, \mathrm{Cl}$ and $\mathrm{K}$ in cultured pig tracheal submucosal gland acinar cells. The data represent means of 59 measurements from three experiments for control cells and 30 measurements from two experiments (using cell cultures from two pigs) for treated cells. Thin bars indicate standard errors. $\boldsymbol{Z}$ : control; $\because \because$ : ionomycin; 22 : 8-bromoadenosine 3':5'-cyclic monophosphate (8-bromo-cAMP). *: $\mathrm{p}<0.05 ; * *: \mathrm{p}<0.01 ; * * *: \mathrm{p}<0.001$, compared to control. 


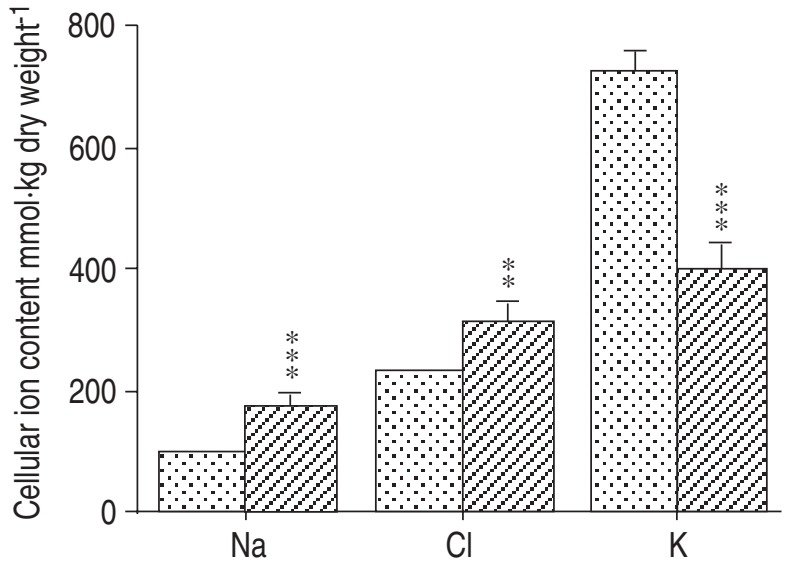

Fig. 5. - Effect of ouabain on the cellular content of $\mathrm{Na}, \mathrm{Cl}$ and $\mathrm{K}$ in cultured pig tracheal submucosal gland acinar cells. Thin bars indicate standard errors. The data are based on three experiments (using cell cultures from two pigs). In each experiment, about 15 cells were analysed. $\because$ : control; $\because$ : ouabain. $* *: \mathrm{p}<0.01, * * *: \mathrm{p}<0.001$, compared to control.

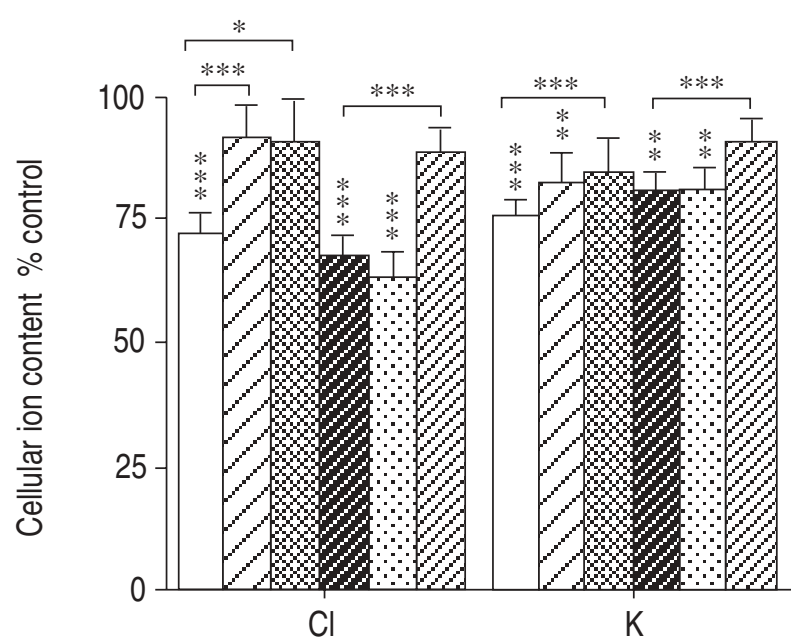

Fig. 6. - Effect of acetylcholine (ACh) and 8-bromo-cAMP, in the absence or presence of chloride channel blockers 9-AC and NPPB, on the cellular content of $\mathrm{Cl}$ and $\mathrm{K}$ in cultured pig tracheal submucosal gland acinar cells. The data are expressed as percentage of control value. Thin bars indicate standard errors. The data are based on two experiments (using cell cultures) from two pigs. In each experiment, about 15 cells were analysed. $\square$ : ACh; $\square: \mathrm{ACh}+9-\mathrm{AC}$; QR : ACh+NPPB; $\boldsymbol{Z}$ : cAMP; $\because \because$ :AMP+9-AC; 22 : cAMP+ NPPB. The brackets with asterisks indicate the significance of the difference between the stimulated cells and the stimulated cells in the presence of 9-AC or NPPB. Other asterisks indicate a statistical significant compared to control. *: $\mathrm{p}<0.05$; **: $\mathrm{p}<0.01$; ***: $\mathrm{p}<0.001$.

\section{Discussion}

Fluid secretion from acini of major exocrine glands (e.g. pancreas and salivary glands) involves a series of ion movements. It is widely accepted that the active $\mathrm{Cl}^{-}$ secretion from the basal side of the epithelia to the acinar lumen and the accompanying passive $\mathrm{Na}^{+}$flux build a local osmotic transepithelial gradient driving water into the lumen [8].

In this report, we demonstrate that the cholinergic agonist acetylcholine, norepinephrine (mainly acting on the alpha-adrenergic receptors) [16] and the beta-adrenergic agonist isoproterenol each induce a significant decrease of intracellular $\mathrm{Cl}^{-}$concentration (fig. 3). The decrease induced by acetylcholine was almost completely inhibited by the $\mathrm{Cl}^{-}$channel blockers $9-\mathrm{AC}$ and NPPB (fig. 6). As with salivary glands $[17,18]$, cultured tracheal acinar cells released $\mathrm{K}^{+}$after stimulation. $\mathrm{K}^{+}$efflux across the basal membrane of acinar cells serves as a driving force by maintaining the cell membrane potential [8]. Our results are in agreement with one in vivo study [19] in which the secretory rate of the submucosal gland, after stimulation with each of three types of receptors agonists, was much greater than in unstimulated glands. UEKI et al. [20] presented similar effects of cholinergic and alpha-adrenergic receptor agonists, but did not report data on beta-adrenergic agonists. However, two in vitro studies using pieces of tracheal walls $[21,22]$ showed a different effect of beta-adrenergic agonist stimulation on fluid secretion. These studies reported that cholinergic and alpha-adrenergic agonists stimulated copious secretion whereas beta-adrenergic agonists had almost no effect. Another difference between results obtained in in vivo [18] and in vitro [21, 22] experiments is that a certain amount of baseline secretion was observed in the in vivo experiments, while almost none was found in the in vitro situation. Possibly denervation and loss of perfusion are responsible for these differences.

Based on Ussing chamber experiments, YAMAYA et al. [23] reported that cell cultures of human tracheal gland acini released $\mathrm{Cl}^{-}$after stimulation with the cholinergic agonist methacholine, the alpha-adrenergic agonist phenylephrine or the beta-adrenergic agonist isoproterenol. It is presumed that cholinergic and alpha-adrenergic agonists act via a $\mathrm{Ca}^{2+}$-dependent pathway while beta-adrenergic agonists act via a cAMP-dependent pathway. To confirm the effect of second messengers on $\mathrm{Cl}^{-}$secretion, we treated cell cultures with the calcium ionophore ionomycin and 8-bromo-cAMP, respectively, and found that both markedly reduced the cellular $\mathrm{Cl}$ and $\mathrm{K}$ concentrations (fig. 4). Although this is the first report directly demonstrating the existence of a cAMPactivated pathway for chloride secretion in the tracheal gland acinar cells [24, 25], this result is not surprising considering the relatively high level of expression of CFTR (a cAMP-dependent $\mathrm{Cl}^{-}$channel) in human tracheobronchial submucosal glands [2, 26].

With freshly isolated acini or confluent cultures of enzymatically isolated acinar cells, two groups $[27,28]$ observed that cells responded to the cholinergic agonist carbachol by releasing $\mathrm{Cl}^{-}$and that the cell response to carbachol was dependent on the ouabain-sensitive $\mathrm{Na}^{+}-$ $\mathrm{K}^{+}$-ATPase pump in the basolateral membrane. In the present study, when the cells were exposed to $1 \mathrm{mM}$ ouabain for $5 \mathrm{~min}$, the expected effects of inhibition of the $\mathrm{Na}^{+}-\mathrm{K}^{+}$-ATPase were observed, namely loss of $\mathrm{K}$ and increase of the cellular $\mathrm{Na}$ and $\mathrm{Cl}$ concentrations (fig. 5).

Our results indicate that the cells in culture retained some of the morphological characteristics of in situ epithelia, and that the specific regulation of ion transport in the submucosal gland cell cultures still existed. We conclude that this system is suitable for studying aspects of ion and water transport by the submucosal gland cells, and that X-ray microanalysis is a convenient way to study simultaneous fluxes of several major ions. 
Acknowledgements: The expert technical assistance of A. Ahlander, M. Ljungquist and L. Ljung is gratefully acknowledged.

\section{References}

1. Reid L. Measurement of the bronchial mucous gland layer: a diagnostic yardstick in chronic bronchitis. Tho$\operatorname{rax} 1960 ; 15$ : 132-141.

2. Engelhardt JF, Yankaskas JR, Ennst SA. Yang Y. Submucosal glands are the predominant site of CFTR expression in the human bronchus. Nature Genetics 1992; 2: 240-247.

3. Snouwaert JN, Brigman KK, Latour AM, et al. An animal model for cystic fibrosis made by gene targeting. Science 1992; 57: 1083-1088.

4. Boat TF, Cheng PW. Biochemistry of airway secretion. Fed Proc 1980; 39: 3067-3074.

5. Sommerhoff CP, Finkbeiner WE. Human tracheobronchial submucosal gland cells in culture. Am J Respir Cell Mol Biol 1990; 2: 41-50.

6. Tournier JM, Merten M, Meckler Y, Hinnrasky J, Fuchey C, Puchelle E. Culture and characterization of human tracheal gland cells. Am Rev Respir Dis 1990; 141: 1280-1288.

7. Goco RV, Kress MB, Brantigan OC. Comparison of mucus glands in the tracheobronchial tree of man and animals. Ann NY Acad Sci 1963; 106: 555-571.

8. Smith PM, Gallacher DV, Sasaki T. Electrolyte and fluid secretion in excrine acinar cells. In: Takishima T, Shimura S, eds. Airway Secretion. New York/Basel/ Hong Kong, Marcel Dekker, 1994; pp. 1-36.

9. Sagström S, Roomans GM, Wroblewski R, Keulemans JLM, Hoogeveen AT, Bijman J. X-ray microanalysis of cultured respiratory epithelial cells from patients with cystic fibrosis. Acta Physiol Scand 1992; 146: 213220.

10. Warley A, Cracknell KPB, Cammish HB, Twort CHC, Ward JPT, Hirst SJ. Preparation of cultured airway smooth muscle for study of intracellular element concentrations by X-ray microanalysis: comparison of whole cells with cryosections. J Microsc 1994; 175: 143-153.

11. Welsh MJ. Anthracene-9-carboxylic acid inhibits an apical membrane chloride conductance in canine tracheal epithelium. J Membrane Biol 1984; 78: 61-71.

12. Gögelein H. Chloride channels in epithelia. Biochim Biophys Acta 1988; 947: 521-547.

13. Stefano AD, Wittner M, Schlatter E, Lang HJ, Englert H, Greger R. Diphenylamine-2-carboxylate, a blocker of the $\mathrm{Cl}^{-}$-conductive pathway in $\mathrm{Cl}^{-}$-transporting epithelia. Pflügers Arch 1985; 405 (Suppl. 1): S95-S100.

14. Mörk AC, Hongpaisan J, Roomans GM. Ion transport in primary cultures from human sweat gland coils studied with X-ray microanalysis. Cell Biol Int 1995; 19: 151-159.

15. Roomans GM. Quantitative X-ray microanalysis of biological specimens. J Electr Microsc Techn 1988; 9: 19-44.

16. Guyton AC. The nervous system. In: Textbook of Medical Physiology, 7th Edn. Philadelphia, Saunders, 1986; pp. 545-697.

17. Burgen ASV. The secretion of potassium in saliva. $J$ Physiol (Lond) 1956; 132: 20-39.

18. Mörk A, Zhang AL, Martinez JR, Roomans GM. Chloride secretion in the submandibular gland of adult and early postnatal rats studied by X-ray microanalysis. Histochem Cell Biol 1996; 105: 297-303.

19. Leikauf GD, Ueki IF, Nadel JA. Autonomic regulation of viscoelasticity of cat tracheal gland secretions. J Appl Physiol 1984; 56: 426-430.

20. Ueki I, German VF, Nadel JA. Micropipette measurement of airway submucosal gland secretion. Am Rev Respir Dis 1980; 121: 135-357.

21. Quinton PM. Composition and control of secretions from tracheal bronchial submucosal glands. Nature 1979; 279: 551-552.

22. Borson DB, Chinn RA, Davis B, Nadel JA. Adrenergic and cholinergic nerves mediate fluid secretion from tracheal glands of ferrets. J Appl Physiol 1980; 49: 1027-1031.

23. Yamaya M, Finkbeiner WE, Widdicombe JH. Ion transport by cultures of human tracheobronchial submucosal glands. Am J Physiol 1991; 261: L485-L490.

24. Sasaki T, Shimura S, Wakui M, Ohkawara Y, Takishima $\mathrm{T}$, Mikoshiba K. Apically localized $\mathrm{IP}_{3}$ receptors control chloride current in airway gland acinar cells. Am J Physiol 1994; 267: L152-L158.

25. Shimura S, Sasaki T, Nagaki M, Takishima T, Shirato $\mathrm{K}$. Extracellular ATP regulation of feline tracheal submucosal gland secretion. Am J Physiol 1994; 267: L159-L164.

26. Kartner N, Hanrahan JW, Jensen TJ. Expression of the cystic fibrosis gene in nonepithelial invertebrate cells produces a regulated anion conductance. Cell 1991; 64: 681-691.

27. Young CM, Farley JM, Dwyer TM. Acetylcholine-stimulated chloride flux in tracheal submucosal gland cells. J Appl Physiol 1988; 65: 1891-1894.

28. Culp DJ, Lee DKP, Penney DP, Marin MG. Cat tracheal gland cells in primary culture. Am J Physiol 1992; 263: L264-L275. 